\title{
Global Warming Needs No Utopian Science but a Dismal Science
}

\author{
Jan-Erik Lane ${ }^{1}$ \\ ${ }^{1}$ Fellow with Public Policy Institute, Belgrade \\ Correspondence: Jan-Erik Lane, 10 Charles Humbert, 1205 Geneva; 559 A, 3rd Floor, Thuya Street, 9 th Quarter, \\ Yangon. Myanmar.
}

Received: December 7, 2016

Accepted: December 20, 2016

Online Published: January 6, 2017

doi:10.20849/ajsss.v2i1.105

URL: http://dx.doi.org/10.20849/ajsss.v2i1.105

\begin{abstract}
As the empirical evidence for the global warming hypothesis augments, not the least for Asia, it is time to take climate change more seriously, starting with major activities to bring down the $\mathrm{CO} 2$ :s and guard against methane. It is no longer enough with small scale experimental activities, but a major policy push is necessary to get rid of coal, stone or wood, replacing it or constructing carbon capture facilities everywhere. Old polluting buses and trucks must be replaced urgently, diesel abandoned, and the closure of atomic plants stopped. South Asia and Eat as well as South East Asia have now to embark upon major big scale policies to stop deforestation and desertification, protect coral reefs and secure fresh water sources. Traditional renewables must be replaced by modern renewables. And the pollution from the immense car park has to be regulated somehow. What is now at stake for Asia at the most dynamic part of the globe is to fulfil Goal I and Goal II in the COP21 decarbonisation Agreement? And no government can be allowed to renege.
\end{abstract}

Keywords: Asian economies, "catch-up", "take-off”, COP21 Goal I, Goal II and Goal III, energy-emission conundrum, J. Sachs' SDG utopianism

\section{Introduction}

Energy is the capacity to do work. Lacking energy, no social system can operate, not even the family. The daily use of energy is almost astronomical on a small Planet Earth, and it has had a trend of steady increase year by year. The governments of the states of the world have obliged the change the prevailing energy pattern profoundly in a short time period of a few decades. Not only may all forms of energy be measured, but all these measures are translatable into each other - a major scientific achievement. One may employ some standard sources on energy consumption and what is immediately obvious is the huge numbers involved - see Figure 1.

Table 1. Energy consumption 2015 (Million Tonnes of oil equivalent)

\begin{tabular}{lll}
\hline & Total & $\%$ \\
\hline Fossil fuels & & \\
Oil & 11306,4 & 86,0 \\
Natural Gas & 4331,3 & 32,9 \\
Coal & 3135,2 & 23,8 \\
Renewables & 3839,9 & 29,2 \\
$\quad$ Hydroelectric & 1257,8 & 9,6 \\
$\quad$ Others & 892,9 & 6,8 \\
Nuclear power & 364,9 & 2,8 \\
& 583,1 & 4,4 \\
& 13147,3 & 100,0
\end{tabular}

Source: BP Statistical Review of World Energy 2016 
But energy is conducive to greenhouse gases (GHG), especially anthropogenic emissions of $\mathrm{CO} 2$ :s, coming the burning of fossil fuels, wood coal and tropical forests. To limit climate change from $\mathrm{CO} 2$ :s and methane, the UNFCCC has established three goals as essential for decarbonisation in this century, namely:

Goal I: halting the upward trend in $\mathrm{CO} 2$ emissions

Goal II: reduction of $\mathrm{CO} 2$ emissions by 40 per cent by 2030

Goal III: almost complete decarbonisation by 2075 .

How are these goals to be promoted? They require a gigantic management effort by the single governments and societies as well as assistance from international governance. The implies mentation problematic is especially difficult, not only because it is a matter of global policy-making in a decentralized approach, putting the chief responsibility with the countries themselves, but because there is vital restriction upon policy implementation, viz. economic development must be maintained.

\section{Theoretical Deliberations}

Before looking at how key countries in Asia perform today in relation to the COP21 goals, we discuss some of the central concepts involved in modelling the links involved, namely GDP-energy-emissions. The emphasis is upon the social sciences' perspective of how governments can coordinate policy effort and implement complicated policies.

\section{a) "Dismal Science" versus Utopianism}

Perhaps it is time to re-read T. Malthus' An Essay on the Principle of Population from 1798, (2008) population keeps growing as well as also the wish to increase the standard of living for the human race. Malthusian pessimism is with us with a vengeance in the form of the energy-emissions conundrums. I will develop this position by means of some pertinent country examples. Insisting upon the positive nature of economics, "positive" referring to the understanding and prediction of the IS, one cannot but realize that sustainable development theory deals with the OUGHT. The gulf between normative utopia and harsh reality forces one to look for how adherents of sustainable economics go from realities to utopian vision.

Take the example of Jeffrey Sachs, stating about $S D G$ (sustainable development goals):

$+\ldots$ the SDGs need the identification of new

critical pathways to sustainability. Moving to a low-carbon

energy system, for example, will need an intricate global

interplay of research and development, public investments

in infrastructure (such as high-voltage direct current

transmission grids for long-distance power transmission),

private investments in renewable power generation, and

new strategies for regulation and urban design.” Source: 2210 www.thelancet.com Vol 379 June 9, 2012

Of course, but what is the likelihood that a carbon tax can be put in place (where, how much) as well as how large is the probability that planning works? How is this beneficial cooperation to be forthcoming? What are the incentive mechanisms?

Sachs realizes the gap between desirability and feasibility, but he confronts the gap by almost religious make beliefs, saying:

"The SDGs will therefore need the unprecedented

mobilisation of global knowledge operating across many

sectors and regions. Governments, international institutions,

private business, academia, and civil society will

need to work together to identify the critical pathways to

success, in ways that combine technical expertise and

democratic representation.” Source: p. 2210, www.thelancet.com Vol 379 June 9, 2012

Again, how is this enormous mobilization to come about? What is at stake for most people who understand the risks with climate change is not the desirability of decarbonisation in some form or another, but feasibility. They 
crux of the matter is: How to promote decarbonisation so that real life outcomes come about? The COP21 framework, and its three objectives, namely:

a) Halting the increase in carbon emissions up to 2020 (Goal I),

b) Reducing CO2:s up until 2030 with some 40 per cent (Goal II),

c) Achieve more or less total decarbonisation until 2075 (Goal III),

will prove too demanding for most countries, I dare suggest. What are the hurdles for any decarbonisation project (whether the COP21 or another), if we stick to the ethos of the social sciences, viz. ethical neutrality being truthfully objective?

\section{b) Methane}

Methane is now the new big warning signal. It is a potent greenhouse gas that, pound for pound, traps more than 80 times as much heat in our atmosphere than carbon dioxide. Sudden and strong increases in this greenhouse gas have been reported, with fear of methane emissions coming from the permafrost.

In addition to methane, oil and gas operations release volatile organic compounds (VOCs) into the air which contribute to coughing, wheezing, asthma attacks, and cancer. Because carbon dioxide persists so long in the atmosphere, the level of atmospheric $\mathrm{CO} 2$ will affect the Earth's climate for centuries, if not longer. By contrast, the level of atmospheric methane affects today's climate, but it does not last nearly as long. Methane is important for the peak temperatures that global warming may ultimately reach. If global warming should be close to 2 degrees Celsius, the OP21 objective, concentrations of methane must down. Since methane has so many sources, it is difficult to control.

The oil and gas industry leaks millions of tons of methane pollution and toxic chemicals into the air that harm peoples' health and speed up climate change. These industrial leaks are like an invisible oil spill happening every day. Oil and gas companies can use infrared cameras to track methane leaks and plug them - or capture excess methane. Obama has told oil and gas companies to plug leaks from oil and gas wells, though these rules may get overturned by Trump. In agriculture with cows, scientists are experimenting with ways to get cows to burp less. Researchers have fed cattle things like infused flaxseed, decreasing methane emissions with 30 percent. Crop scientists are developing new genetically engineered rice varieties not transferring as much methane from flooded paddies into the atmosphere.

Both gases are important in different ways, but zeroing out $\mathrm{CO} 2$ - and finding alternatives to the fossil fuels that dominate our energy system - remains the primary task. Scientists agree though that carbon-dioxide is the primary greenhouse gas we should focus upon for global warming.

\section{c) Energy problematic}

Decarbonisation, resulting from the anthropogenic causes of $\mathrm{CO} 2 \mathrm{~s}$, can only be done when the fundamental pattern of energy consumption is transformed. At the present, energy comes from mainly fossil fuels and wood coal. Energy is the capacity to do work, which implies that energy consumption is a sine qua non for affluence, following A. Smith and J.B. Say among the classics. The utopians like Sachs promise that economic development will not be compromised, as SDG would include the Millennium Development Goals (MDG). He claims:

"The SDGs should therefore pose goals and challenges for

all countries - not what the rich should do for the poor,

but what all countries together should do for the global

well-being of this generation and those to come. Middle income

emerging economies, such as Brazil, China,

India, and others, will be crucial leaders of the SDGs,

and will have their own internal challenges of balancing

growth and environmental sustainability..." Source: p. 2208, www.thelancet.com Vol 379 June 9, 2012

This is like a messianic message. Of course, the big country polluters should do most! Economic growth in advanced nations or economic development in the Third World has been based upon the burning of fossil fuels, besides the fact that extremely poor countries employ massive amounts of wood coal. And most countries, whether it be their governments or their private economies, plan for a sharp increase in energy consumption in the coming decades. 
To understand the real role that energy plays for the economy and GHG:s, we turn to the Kaya model. The basic theoretical effort to model the greenhouse gases, especially $\mathrm{CO} 2 \mathrm{~s}$, in terms of a so-called identity is the deterministic Kaya equation (Kaya and Yokoburi, 1997).

In theories of climate change, the focus is upon so-called anthropogenic causes of global warming through the release of greenhouse gases (GHG). To halt the growth of the GHG:s, of which CO2:s make up about 70 per cent, one must theorize the increase in $\mathrm{CO} 2$ :s over time (longitudinally) and its variation among countries (cross-sectionally).As a matter of fact, $\mathrm{CO} 2$ :s have very strong mundane conditions in human needs and social system prerequisites. Besides the breading of living species, like Homo sapiens for instance, energy consumption plays a major role. As energy is the capacity to do work, it is absolutely vital for the economy in a wide sense, covering both the official and the unofficial sides of the economic system of a country. The best model of carbon emissions to this day is the so-called Kaya model:

(E 1) Kaya's identity projects future carbon emissions on changes in Population (in billions), economic activity as GDP per capita (in thousands of \$US(1990) / person year), energy intensity in Watt years / dollar, and carbon intensity of energy as Gton $\mathrm{C}$ as $\mathrm{CO}_{2}$ per TeraWatt year." (http://climatemodels.uchicago.edu/kaya/kaya.doc.html)

Concerning the equation (E 1), it may seem premature to speak of a law or identity that explains carbon emissions completely, as if the Kaya identity were a deterministic natural law. It will not explain all the variation, as there is bound to be other factors that impact, at least to some extent. Thus, it is more proper to formulate it as a stochastic law-like proposition, where coefficients will be estimate using various data sets, without any assumption about stable universal parameters. Thus, we have this equation format for the Kaya probabilistic law-like proposition, as follows:

$$
\text { (E2) Multiple Regression: } Y=a+b_{1} X_{1}{ }^{+} b_{2} X_{2}+b_{3} X_{3}+\ldots+b_{t} X_{t}+u
$$

Note: $\mathrm{Y}=$ the variable that you are trying to predict (dependent variable); $\mathrm{X}=$ the variable that you are using to predict $\mathrm{Y}$ (independent variable); $\mathrm{a}=$ the intercept; $\mathrm{b}=$ the slope; $\mathrm{u}=$ the regression residual. Note: http://www.investopedia.com/terms/r/regression.asp\#ixzz4Mg4Eyugw

Thus, using the Kaya model for empirical research on global warming, the following anthropogenic conditions would affect positively carbon emissions:

$$
\text { (E3) } \mathrm{CO} 2: \mathrm{s}=\mathrm{F}(\mathrm{GDP} / \mathrm{capita} \text {, Population, Energy intensity, Carbon intensity). }
$$

I make an empirical estimation of this probabilistic Kaya model with a longitudinal test for 1990-2014, i.e. World data 1990 - 2015:

$$
\text { (E4) } \mathrm{Ln} \mathrm{CO} 2=0,62 * \mathrm{LN} \text { Population + 1,28*LN(GDP/Capita) }+0,96 * \mathrm{LN}(\text { Energy/GDP }) ; \mathrm{R} 2=.90 \text {. }
$$

\section{d) Energy-emissions conundrum}

The close link in the Kaya model may be visualized in Figure 1.

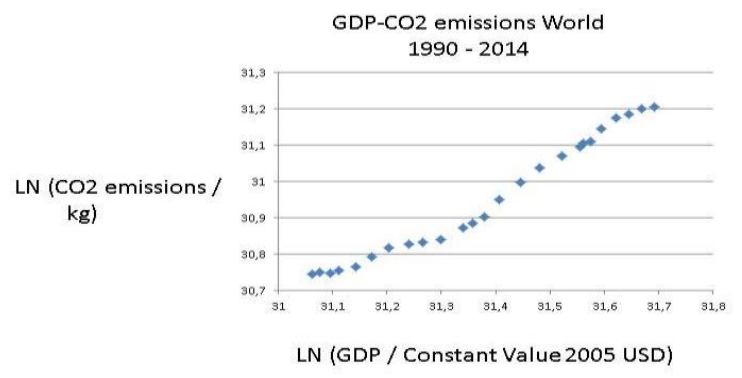

Figure 1. Global GDP-CO2 link: $y=0,80 x+5,96 ; R^{2}=0,97(N=59)$ 
The findings show that total GHG:s or CO2:s go with larger total GDP, i.e. GDP per person * population. To make the dilemma of energy versus emissions even worse, we show in Figure 2 that GDP increase with the augmentation of energy per capita. This makes the turn to a sustainable economy (Sachs, 2015) unlikely, as nations plan for much more energy in the coming decades.

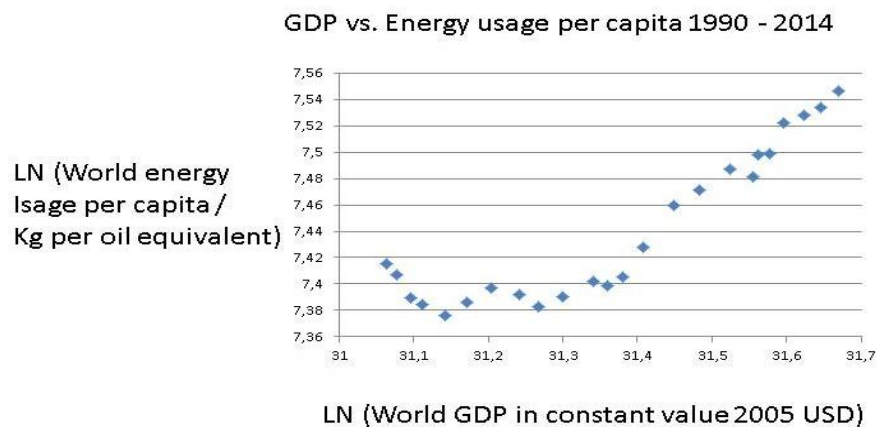

Figure 2. GDP and energy per person 1990-2014

Decarbonisation is the policy promise to undo these "dismal" links by making GDP and energy consumption rely upon carbon neutral energy resources, like modern renewables and atomic energy. Thus, the upward sloping curves must be reversed but still slope outward. Sachs says that decarbonisation can be achieved with a giant global recession, output falling some 20 per cent. But countries would rather renege upon decarbonisation goals. Putting Figures 1 and 2 together, we arrive at the characteristic energy-emissions conundrum. Besides the global conundrum - GDP requires energy, but energy leads to GHG:s - there is an energy-emission conundrum for each government that signed the COP21 Agreement, to be the object of a small inquiry below.

We need to model this energy-emission dilemma for the countries of the COP21 project, targeting the basic hurdles. To understand the predicament of Third World countries, we need to know whether GHC:s or CO2:s are still increasing (Goal I) and what the basic structure of the energy mix is (Goal II). Thus, I suggest:

<GDP-GHG (CO2) link, energy mix>,

as a model of the decarbonisation feasibility in some Third World countries, to be analysed below, following the so-called "Kaya" model. The first concept taps the feasibility of Goal I: halting the growth of GHG:s or CO2:s, whereas the other concepts target the role of fossil fuels and wood coal like charcoal.

To undo an energy-emission conundrum, the price of fossil fuels must increase sharply with a global carbon tax, used to finance the Super Fund. Third World countries need massive financial and technological assistance for ENERGIWENDE. The standard energy projections are completely out of tune with the COP21 project that can save mankind from a climate disaster of major proportions. One encounters these energy scenarios with global oil producers, huge investment banks and the energy organisations: EIA and IEA. They are completely at odds with the decarbonisation objectives, like the COP21 Goals, I, II and III. Something has to give, and I fear economic development trumps the environment and aggravates the energy-emissions conundrum.

\section{Empirical Inquiries}

The countries of the world, participating in the global coordination efforts at decarbonisation of the UNFCCC, face very different conditions for implementing the central policy goals: goal I, II and III. The survey below has the air to show this in detail.

\section{i) THE CATCH-UP STRATEGY}

Several very important Third World nations conduct an aggressive policy of reducing the gap to the First World. Some of them are now in the take-off stage, meaning that have embarked upon the process of industrialisation and urbanization that is irreversible. So far only China has succeeded, as it was Third World up until yesterday. They have no intention to halt their economic advances or slow down economic growth due to a lesser consumption of coal or fossil fuel energy. Let us look at for instance China, I that is responsible for very much of the $\mathrm{CO} 2$ :s.

"Caching-up" countries all have increasing slopes for the GDP-CO2 link, which entails profound difficulties to come for the accomplishment of Goal I in the CO21 project. In relation to the achievement of Goal II, one can 
say only note that tremendous investments have to be made by these countries in renewable energy and atomic plants, which they will find difficult to do.

\section{China}

China has recently made great strides towards halting its increasing $\mathrm{CO} 2$ emissions. Thus, solar, wind and atomic power plants have shot up the last years, but China has to do much more in the form of energy transformation. China was a developing country until yesterday. Now new and bigger cars and aircrafts are multiplying in new extravagant airports.

One finds almost always that the emissions of GHG:s or CO2:s follows economic development closely in Third World countries. The basic explanation is population growth and GDP growth - more people and higher life style demands. Take the case of China, whose emissions are the largest in the world, totally speaking (Figure 3).

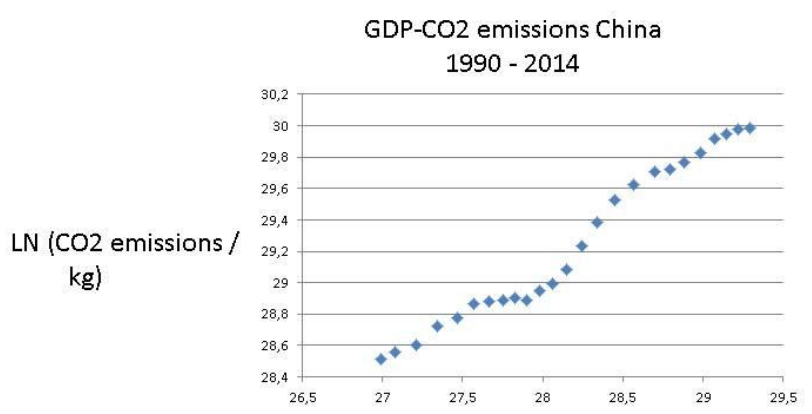

LN (GDP / Constant Value 2005 USD)

Figure 3. China's link GDP-CO2:s: $y=0,70 x, R^{2}=0,97$

The sharp increase in GHG:s in China reflects not only the immensely rapid industrialization and urbanization of the last 30 years, but also its problematic energy mix (Figure 4).

\section{China energy consumption 2014}

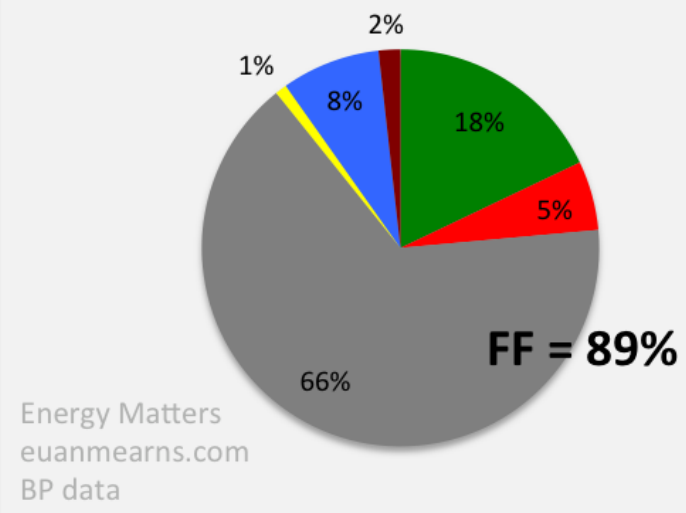

- Oil

Gas

Coal

Nuclear

- Hydro

- Renewables

Figure 4. Energy mix in China 
Almost 70 per cent of the energy consumption comes from the burning of coal with an additional 20 per cent from other fossil fuels. The role of nuclear, hydro and other renewable energy sources is small indeed, despite new investments. This makes China very vulnerable to demands for cutting GHG emissions: other energy sources or massive installation of highly improved filters?

It should be pointed out that several small countries have much higher emissions per capita than China. This raises the enormously difficult problematic of fair cuts of emissions. Should the largest polluters per capita cut most or the biggest aggregate polluters? At the COP21 meeting, this issue was resolved by the creation of a Super Fund to assist energy transition and environment protection in developing counties, as proposed by economist Stern (2007). Will it really be set up with 100 billion dollars per year to spend $n$ energy transformation? Or will some countries renege, like for instance Trump's USA?

In a uniquely rapid economic development over a few decades, China has moved from the Third World to the First World with stunningly new giant cities cropping up and modern infrastructure being introduced to its old cities. With economic growth rates hovering around 10 per cent, China is no longer a poor nation. The trick has been to employ market incentives a la Hayek (1991), resorting to a massive mobilisation of energy, partly imported from Australia among others. Figure 5 has the colossal step in terms of GDP and energy towards a mature economy.

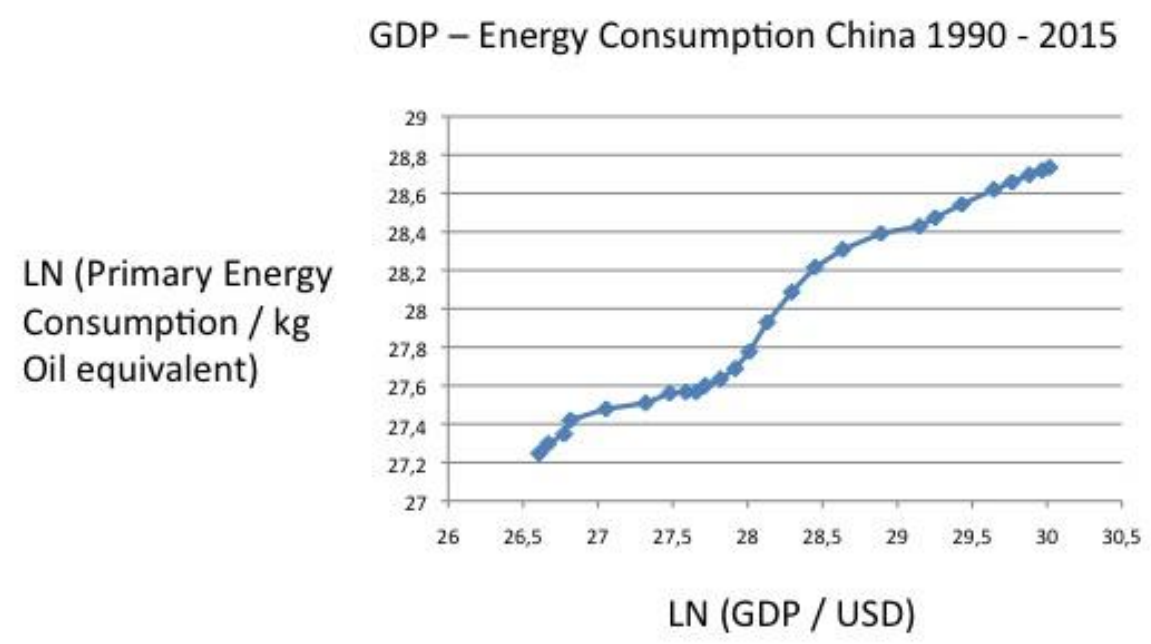

Figure 5. Energy and GDP in Cina: $y=0,46 x ; R^{2}=0,97$

China has multiplied its energy usage several times over, drawing upon internal and external resources, mainly fossil fuels. It used to rely upon internal oil and natural gas, but now it is a major global importer. Its exports are gigantic to the US and the EU, and it is tying other Third World countries into patterns of cooperation, or some would say dominance economically, like African nations and Pakistan. However, the price is not only overall environmental deterioration but also the world's largest $\mathrm{CO} 2$ emissions.

One may guess correctly that countries that try hard to "catch-up" will have increasing emissions. Let us look at three more Asian examples: Thailand and Malaysia as well as Turkey - all emerging economies. Figure 6 begins with Thailand that has become a major car producer. 


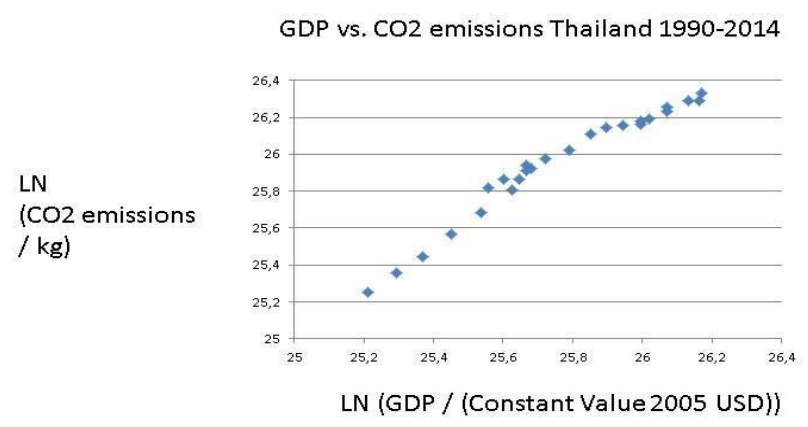

Figure 6. Thailand's GDP-CO2: $\quad\left(y=1,07 x, R^{2}=0,96\right)$

The CO2 emissions in Thailand are quite high, reflecting the economic advances in South East Asia. The trend is up and up. Can it be reversed without serious economic impact? Figure 7 shows the energy mix of this dynamic country, economically.

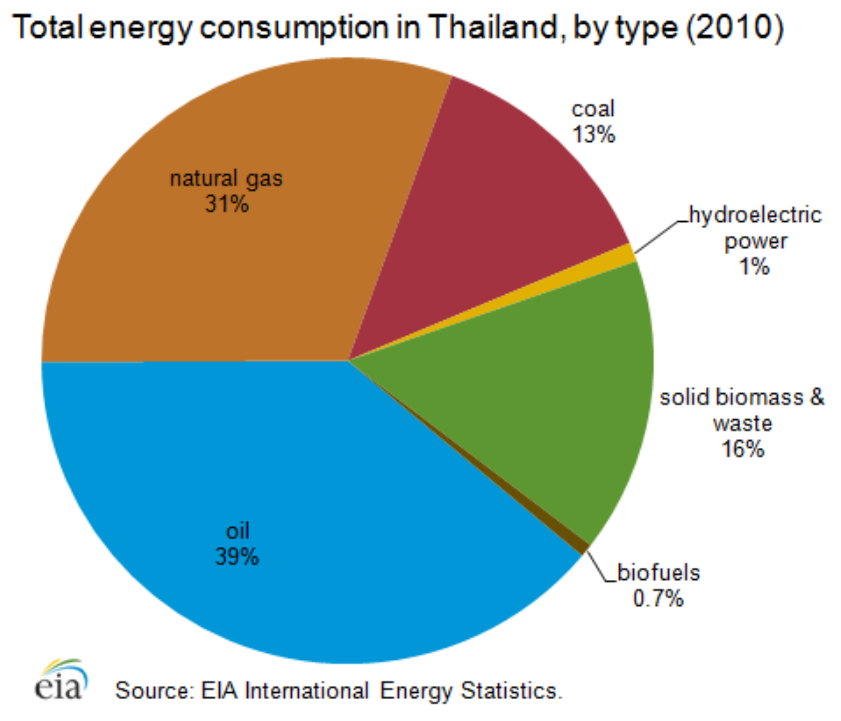

Figure 7. Thailand's energy mix

The reliance upon fossil fuels is high, or over $80 \%$ of energy consumption coming from the burning of coal, oil and natural gas. Hydro power is marginal, but bio-energy plays a major role, but it is really not carbon neutral. Thailand needs to come up with far-reaching reforms of its energy sector in order to comply with COP21 objectives.

\section{Malaysia}

The overall situation - fossil fuels dependency - is the same for Malaysia as for Thailand. And the CO2:s are high, following the GDP trend (Figure 8). 
GDP vs. CO2 emissions Malaysia 1990-2014

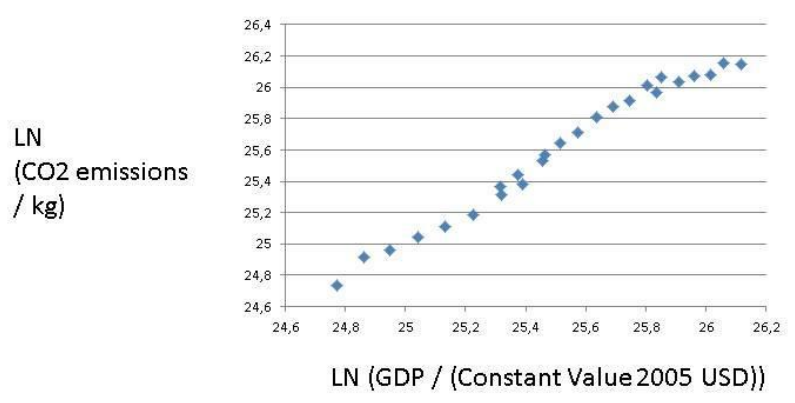

Figure 8. Malaysia's GDP-emission link: $y=1,13 x ; R^{2}=0,98$

Yet, Malaysia employs energy of a very mixed bag (Figure 9), but still its emissions augment in line with economic development. There may be a planning out of the growth trend in emissions recently, but Malaysia use very little of carbon neutral energy sources. There is hydro power, but the country must move to solar and wind power rapidly.

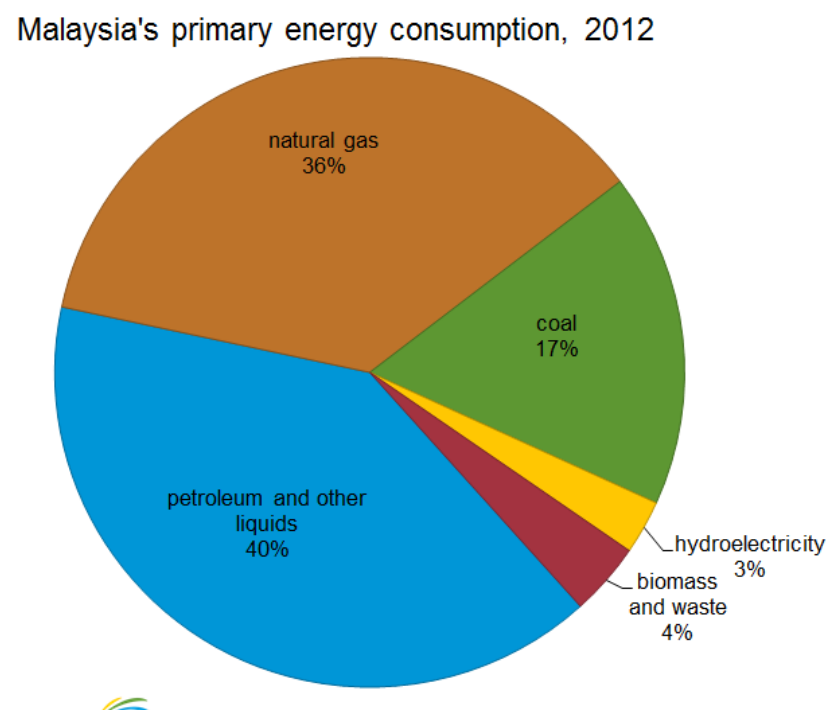

eia Source: U.S. Energy Information Administration

Figure 9. Energy mix in Malaysia

Renewables are not a major element in the energy consumption mix of Malaysia, as fossil fuels dominate, but not coal luckily.

\section{Turkey}

Turkey has become a heavy-weight in the Asia Minor. Figure 10 supports this picture of Turkey as no longer a poor developing country. Comparing the picture for Turkey with that of "catch-up" nations, one may state that Turkey has the typical GDP-GHG link, despite lots of hydro power. Strong economic development is combined 
with heavy emissions increase. Since the world organisations - the UN, WB and IMF - opt for more of economic growth, one must ask whether emissions growth really can be halted.

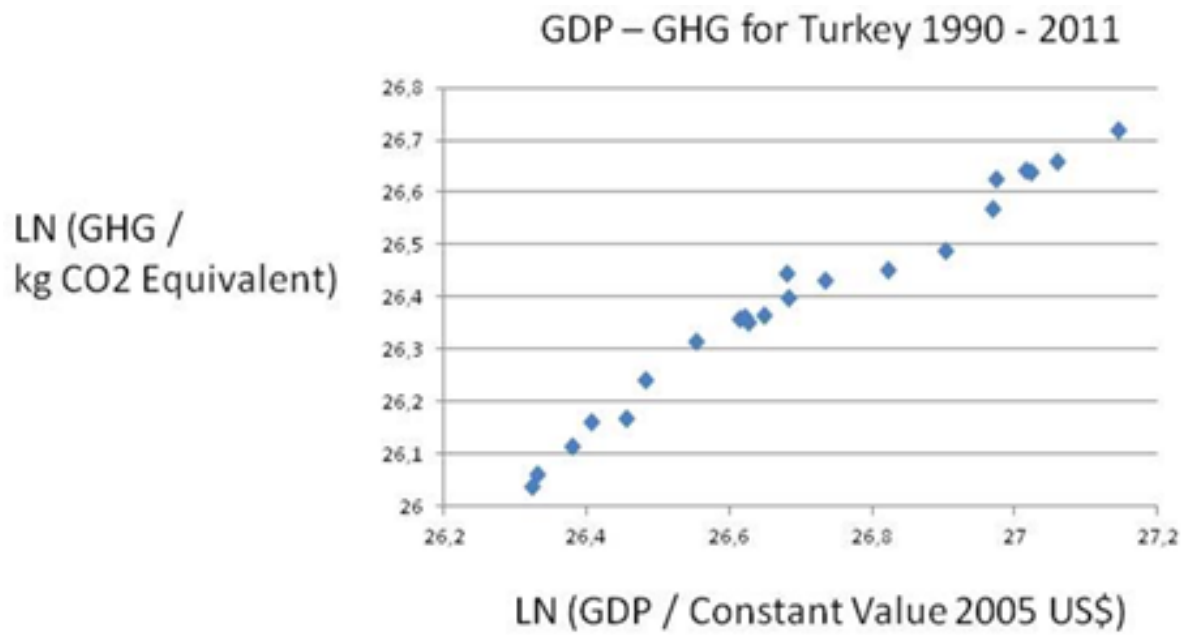

Figure 10. Turkey: GDP-GHG: $\mathrm{Y}=0,78 \mathrm{x} ; \mathrm{R}^{2}=0,97$

The strongly upward sloping curve for emissions may be related a large increase in energy consumption for the same period (Figure 11).

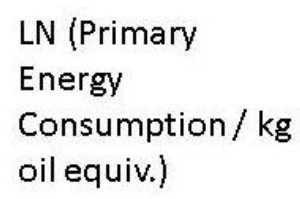

Figure 11. Turkey: GDP-energy: $y=0,90 x ; R^{2}=0,99$

The most dominating country in Asia Minor is Turkey with a huge population and expansing economy. Of course, we find the GDP-energy-emissions conundrum.

TO SUM UP: Countries pursuing the catch-up strategy (Barro, 1991). in relation to the mature economies will hardly accept reductions in their GDP as a cost to pay for participation in the COP21 project. This is actually even more the case when we come to the poor nations having experienced their so-called "take-off", i.e. the decisive point of accelerated market growth.

ii)

THE TAKE-OFF STAGE

\section{India}

India will appeal to the same fairness problematic as other Third World nations, namely low per capita emissions in the Third World against huge aggregate emissions. The country is even more negative than China to cut GHG or $\mathrm{CO} 2$ emissions, as it is in an earlier stage of industrialization and urbanization - the take-off stage (Rustow, 1960). India relies upon wood coal in a massive way, like central Africa. It has been claimed that wood coal is carbon neutral, but in reality it leads to deforestation and desertification on a huge scale. 
Figure 12 shows the close connection between emissions and GDP for this giant nation.

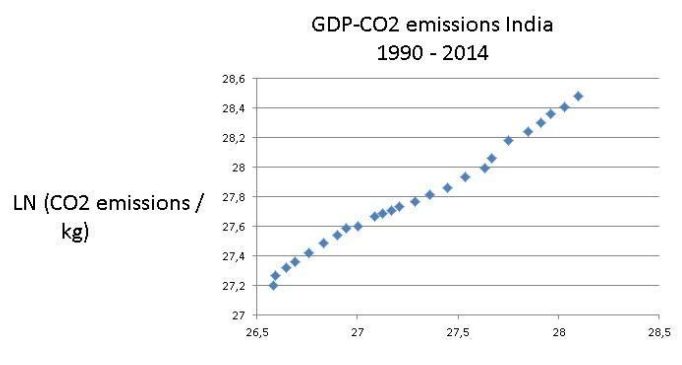

LN (GDP / Constant Value 2005 USD)

Figure 12. India's link GDP-CO2: $y=0,7702 x+6,79 ; \mathrm{R}^{2}=0,99$

India needs cheap energy for its industries, transportation and heating as well as electrification. From where will it come? India has water power and nuclear energy, but relies most upon coal, oil and gas as power source. It has strong ambitions for the future expansion of energy, but how is it to be generated, the world asks. India actually has one of the smallest numbers for energy per capita, although it produces much energy totally. Public intellectual and former minister Ramesh (2015) admits openly that India cannot do without stone coal fired power stations for socio-economic development reasons. In addition, India relies massively upon wood coal.

Figure 13 shows its energy mix where old or traditional renewables play a bigger role than in China.

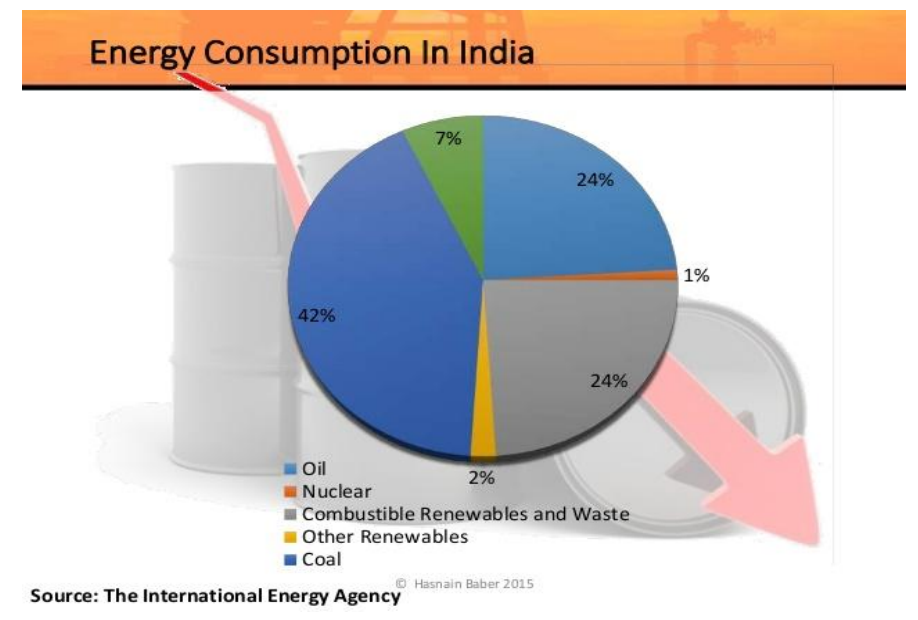

Figure 13. Energy mix in India

India needs especially electricity, as 300 million inhabitants lack access to it. The country is heavily dependent upon fossil fuels (70 per cent), although to a less extent than China. Electricity can be generated by hydro power and nuclear power, both of which India employs. Yet, global warming reduces the capacity of hydro power and nuclear power meets with political resistance. Interestingly, India uses much biomass and waste for electricity production, which does not always reduce GHG emissions. India's energy policy will be closely watched by other governments and NGO:s after 2018.

Energy consumption in India is planned to augment over the coming decade, as the ambition is to provide electricity to the whole population. Some 300 million people are today without electric power, and the 
population of India is growing fast. Mass povertyis the only outcome of this imbalance between total energy and total population, where India is heading for becoming the largest country in the world soon population wise. Public intellectual and former minister Ramesh (2015) states that India has no alternative but to build more coal firef energy plants. Thus, we may expect that Figure 14 will show more of an upward trend in the decade to come.

\section{GDP - Energy Consumption India 1990 - 2015}

LN (Primary Energy Consumption / kg Oil equivalent)

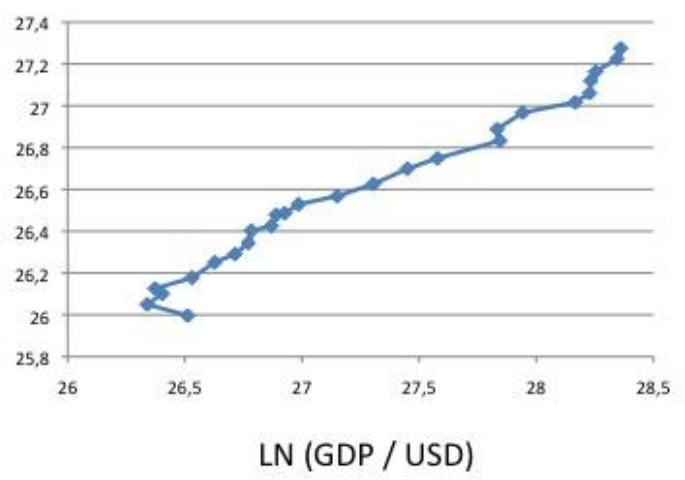

Figure 14. India: GDP-energy link: $y=0,55 x ; R^{2}=0,98$

Besides burning lots of fossil fuels, Indian housholds rely much upon wood coal in its various forms, uch as charcoal, peat and dung. Wood coal is detrimental to people and the environment. As wood coal releases CO2:s, the use of biomass is typically defended by the argument that it also stores $\mathrm{CO} 2$, meaning that biomass would be basically carbon neutral. However, this argument completely bypasses that wood coal in poor nations is conducive to deforestation and desertification, which is what happens on a large scale in India.

\section{Indonesia}

One may guess correctly that countries that try hard to first to leave the "take-off stage" and then move on to the "catch-up" stage will have increasing emissions. This was true of China and India. Let us look at a few more examples, like e.g. giant Indonesia - now the fourth largest emitter of GHG:s in the world (Figure 9).

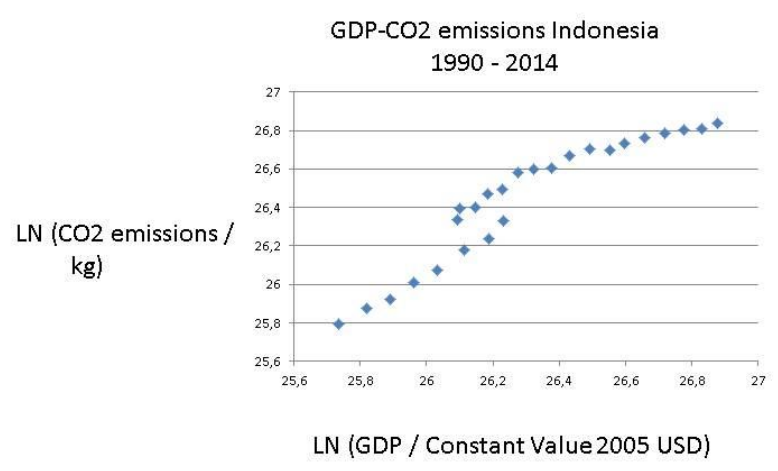

Figure 15. Indonesia's link GDP-CO2: $y=0,95 x+1,58 ; \mathrm{R}^{2}=0,88$ 
Indonesia is a coming giant, both economically and sadly in terms of pollution. Figure 16 reminds of the upward trend for China and India. However, matters are even worse for Indonesia, as the burning of the rain forest on Kalimantan augments the GHG emissions very much.

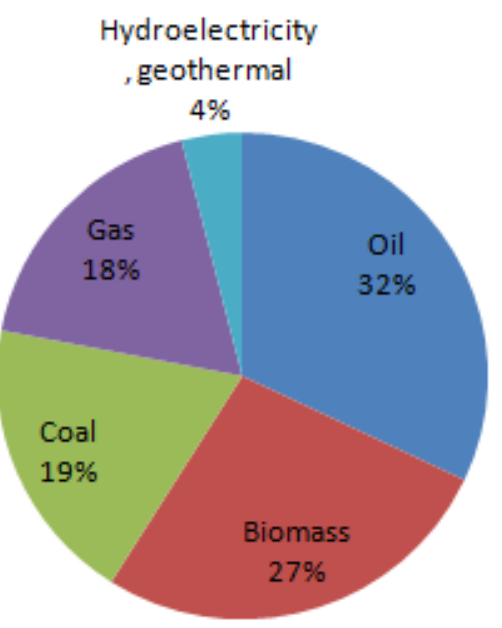

\section{Distribution of Energy Consumption in Indonesia in 2009}

Figure 16. Energy mix

(http://missrifka.com/energy-issue/recent-energy-status-in-indonesia.html)

Only 4 per cent comes from hydro power with 70 per cent from fossil fuels and the remaining 27 per cent from biomass, which alas also pollutes.

Indonesia has rapidly moved up as a major consumer of energy in the early 21 rst decade., refelcting growimh political stability and a strong effort to catch-up with the other Asian miracles. It has definitely passed its "take-off" point, but interestingly its enormous consumption of energy has not been accompanied by high real economic growth in most recent years (Figure 17)
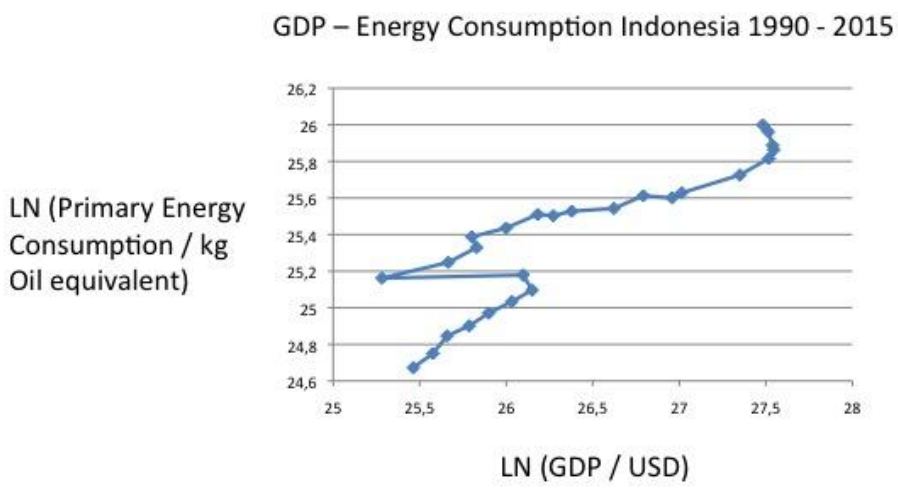

Figure 17. Indonesia: GDP-energy link: $y=0,46 x ; R^{2}=0,79$

The inward and upward sloping curve for Indonesia must be of concern to the elite in the country, because Indonesia has become a major contributor to $\mathrm{CO} 2$ emissions. If economic growth stalls due to inflation, then how to defend the enormous emissions?

\section{Vietnam}

The catch-up strategy is global, to be found not only in Asia but also in Latin America and Africa. These countries are all on the upward sloping curve for GDP, energy and emissions. They will accept the COP21 goals, but demand compensation, heavy financial support for energy transformation. 
The CO2-energy-emissions conundrum that Third World countries all over the world faces, can be observed in two populous nations in Asia with rapidly expanding economies: Vietnam and the Philippines. They have both upward sloping trends for emissions, energy consumption and GDP, as the Kaya model entails.

Vietnam is now one of the most dynamic economy in Asia, after years of socialism and a planned economy. Such fast economic growth requires one thing especially, namely energy (Figure 18).

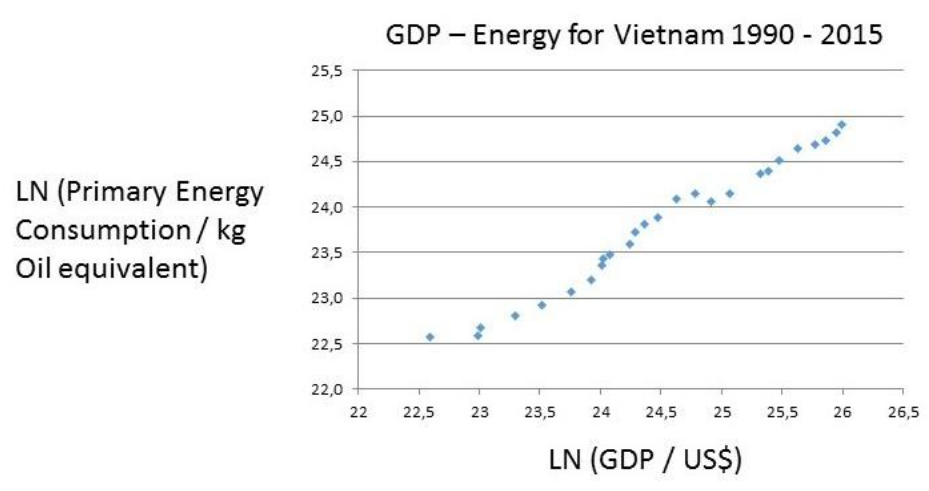

Figure 18. Vietnam: GDP and energy $\left(y=0,74 x ; R^{2}=0,98\right)$

The benefits of such a strong economic development is of course raising affluence and diminishing poverty. But the costs involve much more emissions (Figure 19).

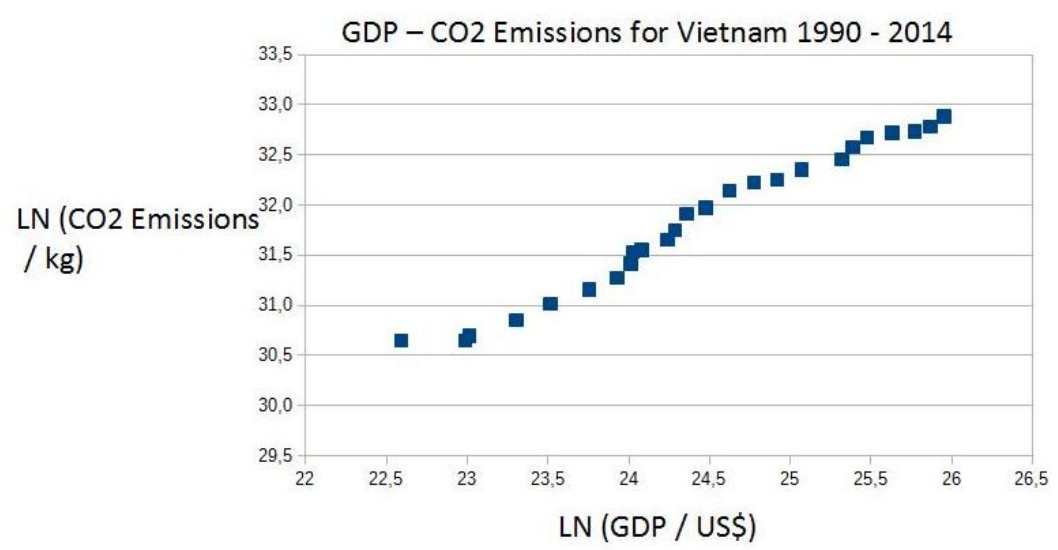

Figure 19. GDP and emissions for Vietnam: $y=0,75 x+13,37 ; \mathrm{R} 2=0,98$.

How Vietnam is to change in order to promote the COP21 goals, Goal I and Goal II) within a short period of some 10 years, given the ambition to maintain raid economic growth, is very difficult to understand. Can really modern renewables do the trick? It is a highly relevant policy question, despite the massive employment of hydro power in this country.

\section{THE PHILIPPINES}

Giant nation the Philippines is very interesting, as they claim that they can handle the implementation of the COP21 goals. This may simply be rhetoric, which is just another form of reneging upon promises. Consider first the upward sloping trend in Figure 20. 


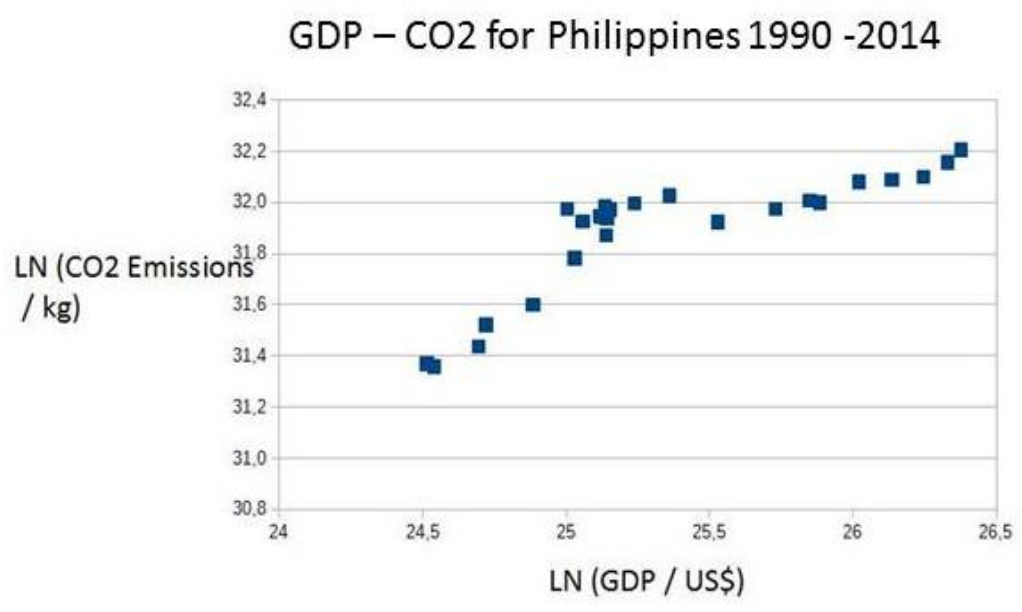

Figure 20. The Philippines: $y=0,36 x+23,01 ; R 2=0,68$

As the GDP-CO2 curve is upward sloping, on wonders how this country shall meet its COP21 obligations. They say they have much geo-thermal power, but they still must cut back fossil fuels considerably, while maintaining economic development for its huge poor population (Figure 21).

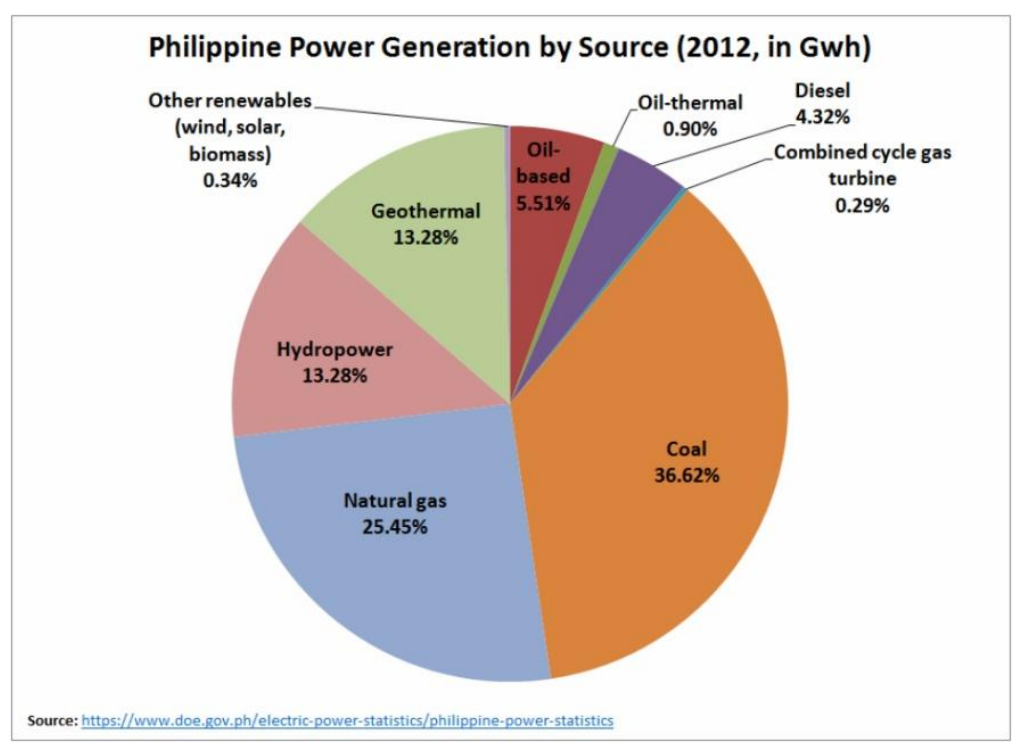

Figure 21. Energy mix in the Philippines

The energy profile of the Philippines is actually more positive than several of the countries above, including a huge part of geo-thermal energy. Yet, fossil fuels dominate to a high 70 per cent, as in other populous and rapidly developing nations. The Philippines definitely needs help from the Super Fund. 
LN (Primary Energy Consumption / kg Oil equivalent)

GDP - Energy for Philippines 1990 - 2015

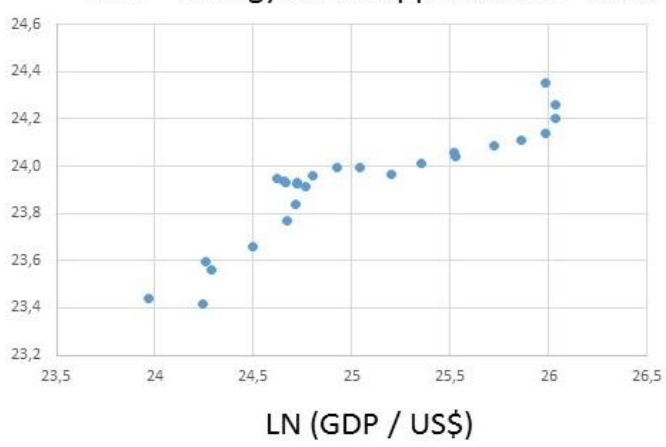

Figure 22. The Philippines: GDP-energy: $0,34 \mathrm{x} ; \mathrm{R}^{2}=0,81$

To sum up: Nations going foward from its "take-off" point in tome (Rustow, 1960) bet much upon the growth implications of cheap energy. Their energy transformation depends upon support from the promised Super Fund.

iii) NO INCENTIVES

Several countries like for instance some of the Gulf States or emirates have massive CO2:s, because they drill and refine oil and natutal gas. Of couse, they burn in order to get electricity. Will they be motivated to reduce these fossil fuels and turn to solar or wind power? Well, it depends upon the economics or costs of energy trasfomation.

\section{THE MIDDLE EAST}

One may of course look at the leader of the OPEC Saudi Arabia, but the basic picture is trivial and recurs with Kuweit and the UAE as well as Qater. Saudia Arabia burns oil and gas to maintain a very high standard of living, based upon abundant electricity. They have so much electricity that they can construct Green Oasis Towns.

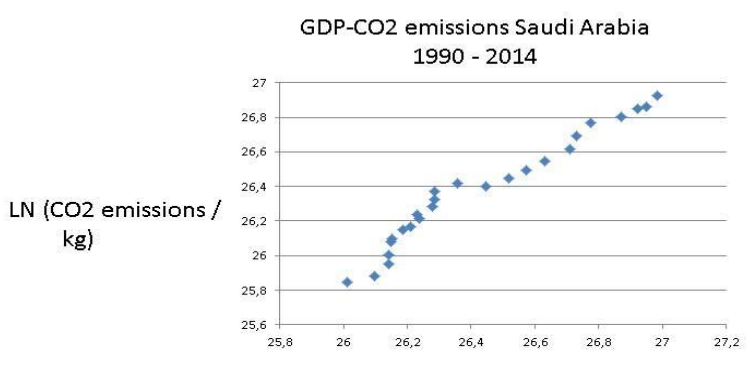

LN (GDP / Constant Value 2005 USD)

Figure 23. Link GDP-CO2:s for Saudi Arabia: $y=1,03 x-0,77 ; R^{2}=0,95$

The recent economic downturn for this oil richest country in the world may spark a real turn to modern renewables. Yet, atomic power contructed by South Korea is an attractive option, only as long as the oil price stays moderately high. Solar power would of course be an option, but it is far less effective that burning oil and natural gas. 
These oil rich countries burn massive amounts to get electricity that is the basis for a very high standard of living. On a per capita basis, the emissions in these countries are far higher than in popolous the catch-up countries. Perhaps they should contribute more to the Super Fund? The same question of fairness is apparent in the Kuweit and UAE data, where CO2 emissions are the highest in the world except for Qatar. The UAE has the charactiristically upward slopig trend,

\section{Iran}

If Iran can continue to enter the global enery market, it is large enough both as a producer and a consumer to impact climate change. To shift to modern renewables ot atomic power, it needs a decent price for its fossil fuels. Figure 23 shows the standrad upward trend for the oil countries.

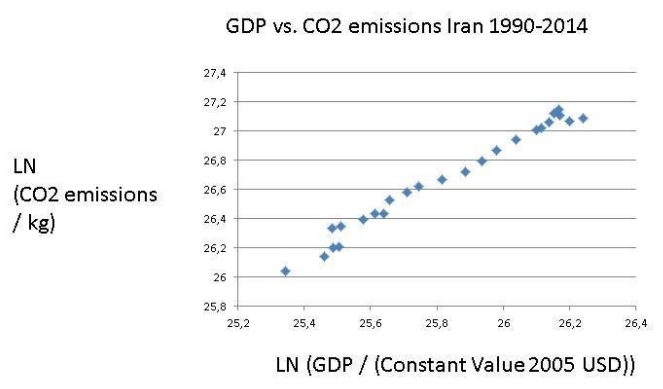

Figure 23. Iran: GDP-CO2 link: $y=1,22 x-4,91 ; R^{2}=0,98$

Iran is together with Russia and Qatar the largest owner of natural gas deposits. But despite using coal in very small amounts, its $\mathrm{CO} 2$ emissions are high. Natural gas pollute less than oil and coal, but if released unburned it is very dangerous as a greenhouse gas. Iran relies upon its enormous resources of gas and oil (Figure 24).

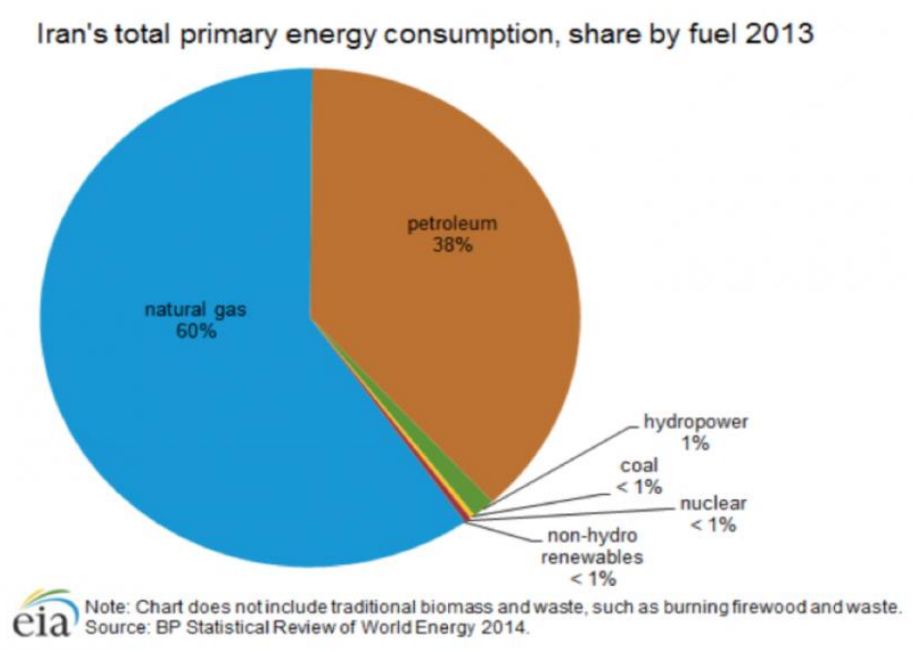

Figure 24. Iran: Energy mix

Iran needs foreign exchange to pay for all its imports of goods and services. Using nuclear power at home and exporting more oil and gas would no doubt be profitable for the country. And it would also help Iran with the COP21 goals achievement. 


\section{Kazakhstan}

Also countries with no hydro power display increasing trends for emissions. Consider an oil and gas rich country in central Asia.

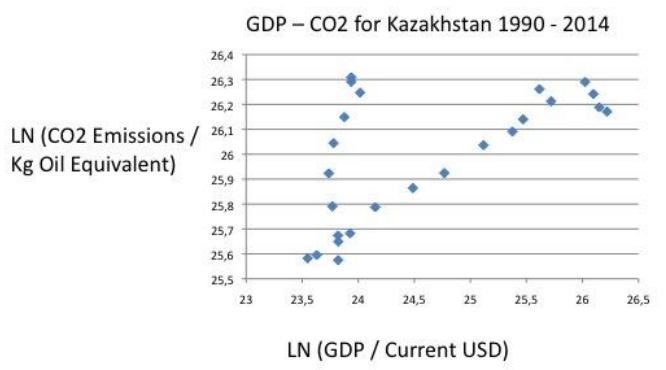

Figure 25. Kazahkstan's link GDP-CO2: $y=0,17 ; \mathrm{R}^{2}=0,38$

Kazahkstan employs its vast fossil fuel resources for energy consumpton besides exporting a lost.

Here we have a nation very much occupied with the catch-up strategy. It wants to copy the Asian miracles, moving to affluence in a few decades, using its immense fossil energy resources (Figure 26).

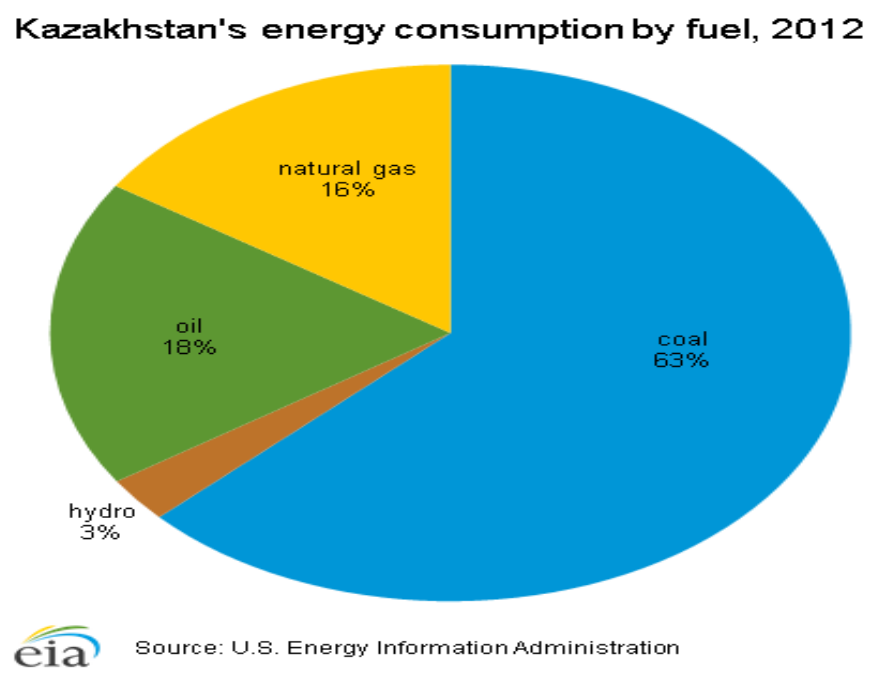

Figure 26

However, this energy consumption leads to enormous emissions (Figure 15). The stunning economic development, including the great project of a modern Silk Roan from China to Germany through Kazakhstan implies that the CO21 goals cannot be accomplished here. Catch-up and huge infrastructure trumps climate change.

Summing up: Oil and natural gas producing countries will only start massive energy transformation, if the price of oil or gas is considerably high. The shale rock revolution may hinder that, as American exports pick up. There 
is incredibly much shale rock in former USSR. When solar panels and atomic power is costly, why not burn the petrol you have, for cars or electricity generation?

\section{iv) NO RESOURCES}

Decarbonisation requires massive new investments. Many countries are in such economic troubles that they just cannot make them. Either they have to renege or they must be assisted by some kind of Super Fund. One example that comes to mind is the unfortunate country in Latin America that faces profound political instability.

The same upward trend for emissions holds for another major developing country with huge population, namely Pakistan (Figure 27).

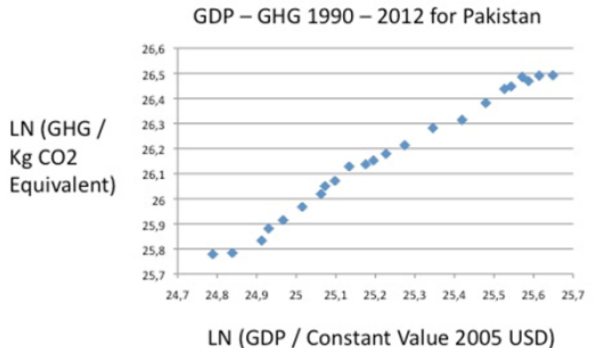

Figure 27. Pakistan: LN (GHG / Kg CO2 eq and LN (GDP / Constant Value 2005 USD)

The amount of GHG emissions is rather large for Pakistan, viewed as aggregate. Pakistan is mainly reliant upon fossil fuels (Figure 28).

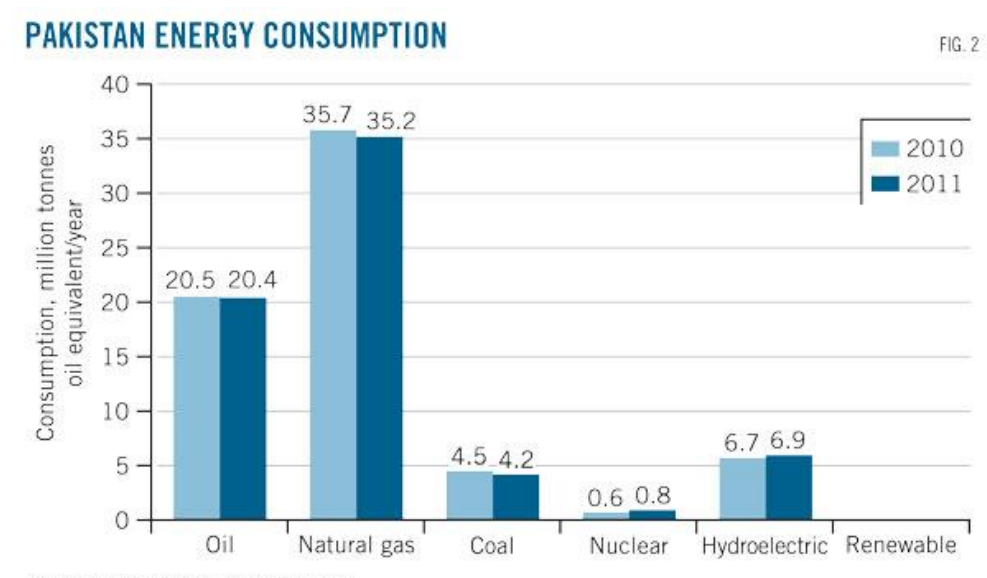

Source: BP Statistical Review of World Energy 2012

Figure 28. Energy mix in Pakistan

But Pakistan employs a considerable portion of hydropower - 13 per cent - and a minor portion of nuclear power, which is a positive.

Moving on to another giant nation in South Asia, Bangladesh, we find an entirely different set of conditions for implementing COP21. In Bangladesh like in all South Asian countries, the GHC:s or CO2:s follows economic development closely. Yet energy consumption in this very poor nation is based on a different energy mix, 
compared with for instance India. Figure 29 pins down the large role of traditional renewables like wood, charcoal and dung as well as the heavy contribution of oil and gas. Bangladesh needs external support for developing modern renewables, like solar, wind and geo-thermal power sources.

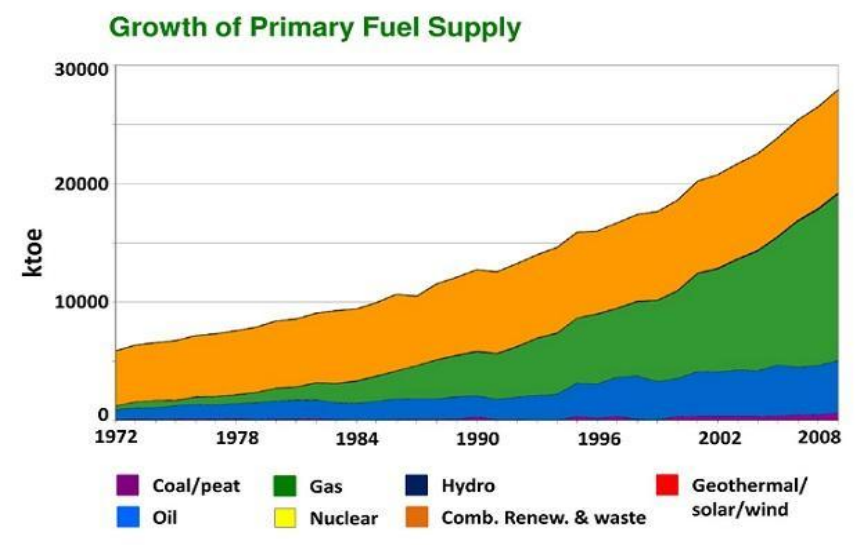

Figure 29. Bangladesh: energy mix

Source: Energy Scenario in Bangladesh from 1972-2008 (Orange: Biomass, Green: Gas, Blue: Oil)

To sum up: I believe most countries "taking-off" in Rostow's (1960) terminologywill rely much upon fossil fuels, like the examples above. It can be pointed out that one finds no example of declining GDG-CO2(GHG) links in Latin American nations, nor in Africa or Asia, meaning that COP21 management will struggle to get GOAL I implement. But it is not difficult to identify countries can will need much assistance from the Super Fund: Egypt, South Africa, Nigeria, Peru, Venezuela, Argentina, Brazil, etc.

\section{v) RENEGING}

At the end of the day, some countries may simply renege upon the COP21 or decarbonisation. They may find it unwarranted from a scientific point of view (Trump's USA) or they feel they cannot afford an immense energy transformation.

\section{USA}

The US is a major carbon polluter, both in aggregation and per person. Figure 30 shows its dependence upon fossil fuels.

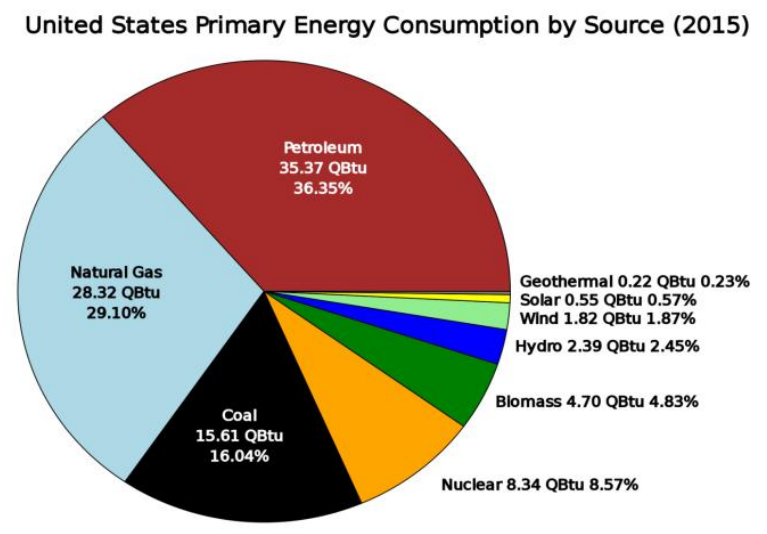

Figure 30. Energy mix for the US

Yet, the positive signs for the US include a downward sloping curve in Figure 31. But as solar power and wind power expands, so atomic power is reduced and shale oil and gas augmented. Politics will be decisive here, as the US may renege upon the COP21 decarbonisation goals. 


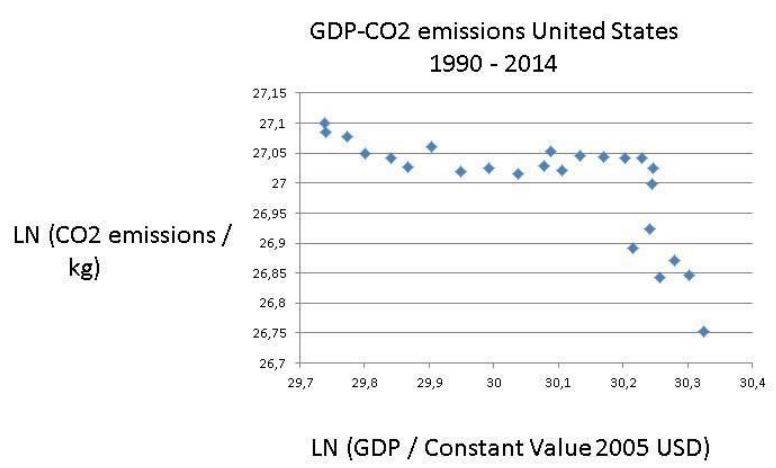

Figure 31. USA: Link GDP-CO2: $y=-0,32 x+36,7 ; \mathrm{R}^{2}=0,49$

Developments in the US are promising, as most countries display upward sloping GD-GHC (CO2) links. But to comply with the draconic COP21 goals, the US needs to do much more. Will it, or will the Trump administration renege? There is no clear and consistent energy policy in the US (Figure 32).

\section{GDP - Energy Consumption United States 1990 - 2015}

\section{LN (Primary Energy Consumption / kg Oil equivalent)}

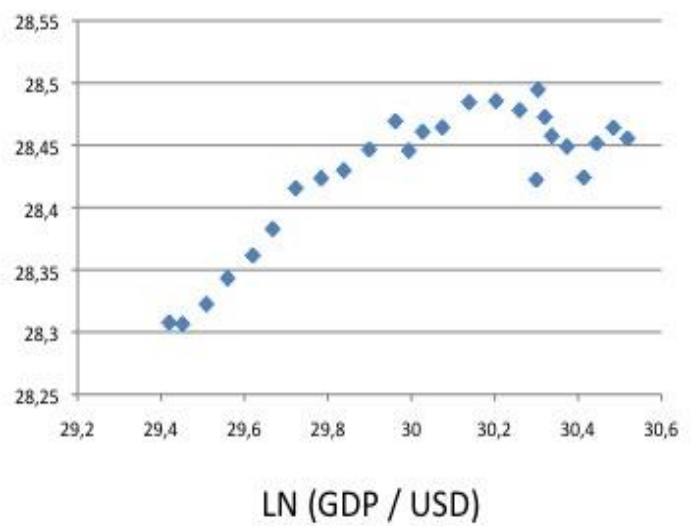

Figure 32. Energy and GDP: $y=0,46 x ; R^{2}=0,97$

The plans of the EPA and the EIA for future energy needs in the US include a heavy augmentation, but one cannot tell whether it will come about from renewables or fossil fuels like fracking. The market for energy is somewhat bewildering in the country with the start of oil and natural gas exports again as well as the shut down of atomic power plants. Yet, fracking is not environmental friendly. Lots of solar plants are coming up, but their efficiency is low compared with nuclear plants.

\section{AUSTRALIA}

When one goes beyond the EU, one finds only two cases of declining GDP-COP curve: Australia and Japan. Japan has for a long time substituted coal for atomic power, although recently with a crucial set. But Australia has always been the country of fossil fuels, exporting coal and iron in huge amounts. However, it has reached its 
$\mathrm{CO} 2$ peak recently (Figure 33).

GDP - CO2 for Australia 1990 - 2014

LN (CO2 Emissions / kg

of oil equivalent)

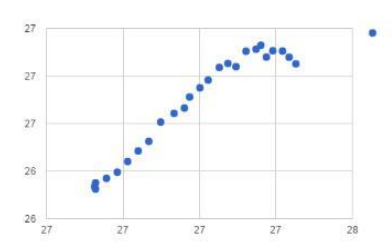

LN (GDP / Constant Value 2005 \$)

Figure 33. Australia's GDP-CO2 link

Australia has been extremely dependent upon fossil fuels, domestically and in exports in Asia. Cutting back its coal dependency will allow the country to halt its $\mathrm{CO} 2$ emissions, while moving to renewables. The fossil fuel dependency of Australia is simply stunning (Figure 34).

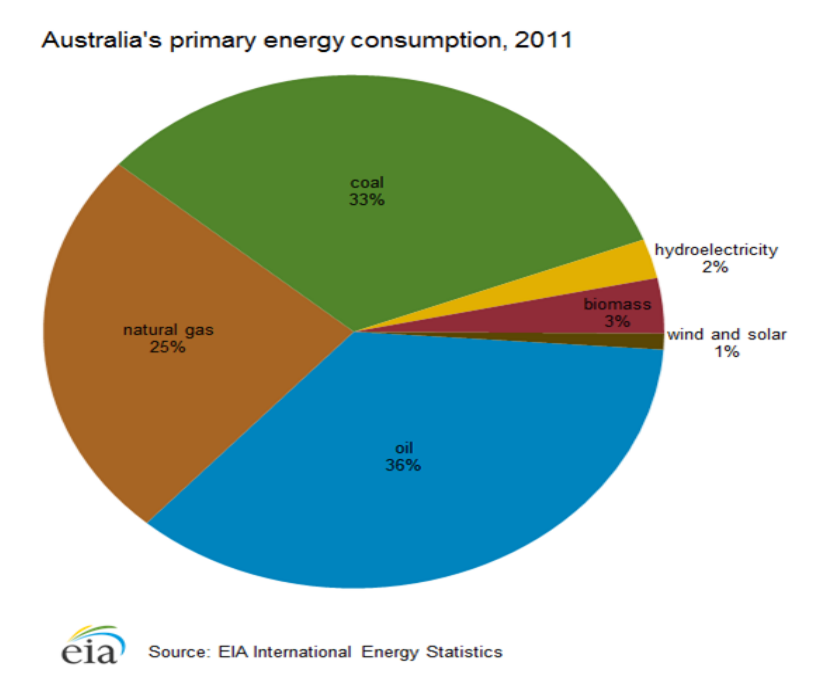

Figure 34. Energy mix in Australia

Australia has often been accused of fuelling climate change. These accusations appear to be vindicated in the Figure above that shows an extreme reliance upon fossil fuels. Add then all the export of raw materials! One prime minister of Australia has declared that the country will reduce $\mathrm{CO} 2$ :s only if economic growth is not hurt. It remains to be seen how Australia tackles Goal I and Goal II. Prime ministers have expressed an Australian preference: first growth, second decarbonisation. Can the country really give up coal?

\section{SOUTH KOREA}

A major industrial country in East Asia is South Korea with an advanced economy and large population. It deviates from the pattern of mature economies to display a slowing down in the CO2:s (Figure 35). 


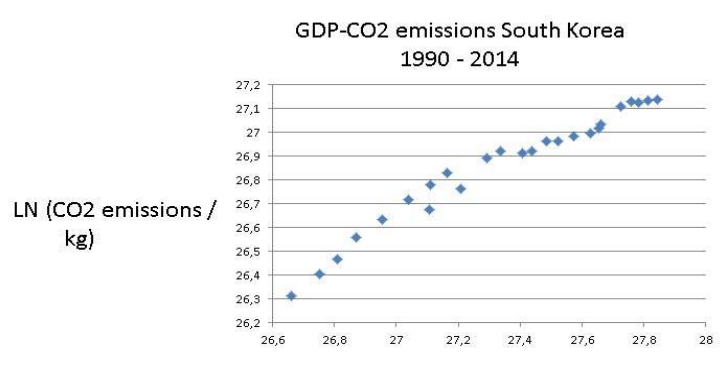

LN (GDP / Constant Value 2005 USD)

Figure 35. South Korea: GDP=CO2 link: $y=0,65 x+9,19 ; R^{2}=0,96$

Lacking much hydro power, South Korea has turned to fossil fuels for energy purposes, almost up to 90 per cent. Now, it builds nuclear plants, but South Korea needs to move aggressively into solar power to reverse trends. It differs from China only in the reliance upon nuclear power, where the country is a world leader in plant constructions. Reducing its GHG emissions, South Korea will have to rely much more upon modern renewable energy sources, as well as reducing coal and oil for imported gas or LNGs. Its appetite for energy is not slowing down (Figure 36).

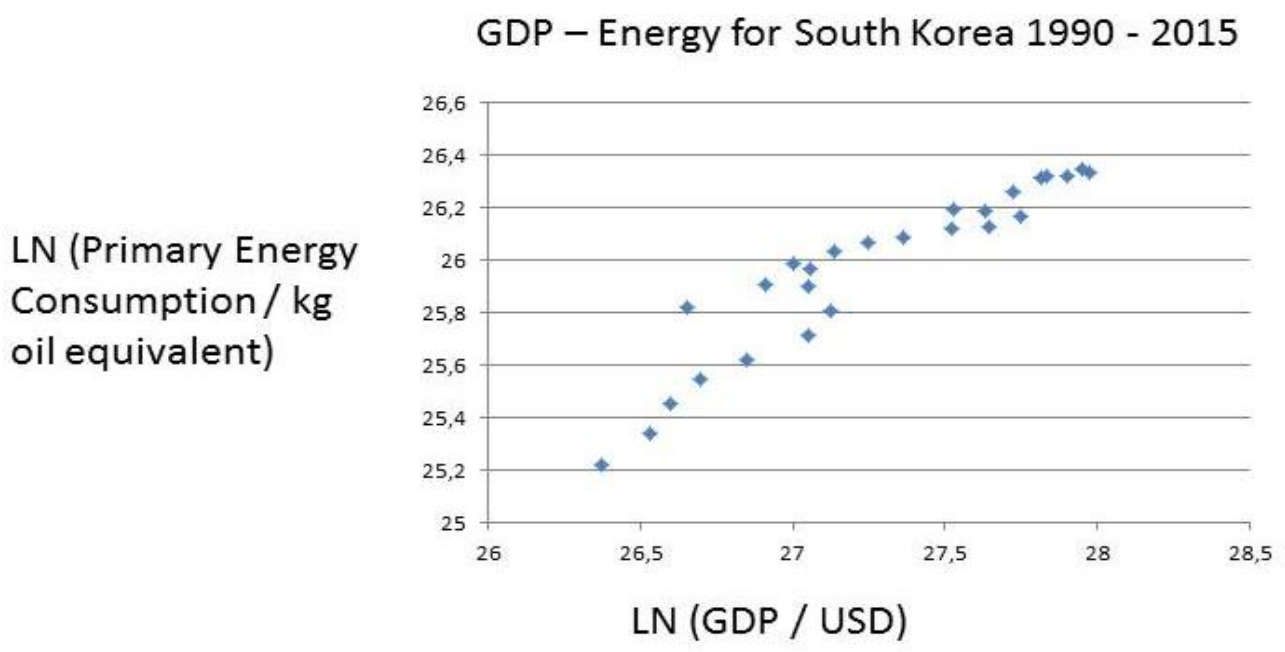

Figure 36. GDP-energy for South Korea: $y=0,622 x ; R^{2}=0,88$

South Korea is of course a mature economy, but it still pursues an aggressive catch-up strategy with strong claims in electronics and nuclear power technology besides shipping and car industry.

Lacking much hydro power, South Korea has turned to fossil fuels for energy purposes, almost up to 90 per cent (Figure 37). Now, it builds nuclear plants, but South Korea needs to move aggressively into solar power to reverse trends. 


\section{South Korea total primary energy consumption \\ by fuel type, 2012}

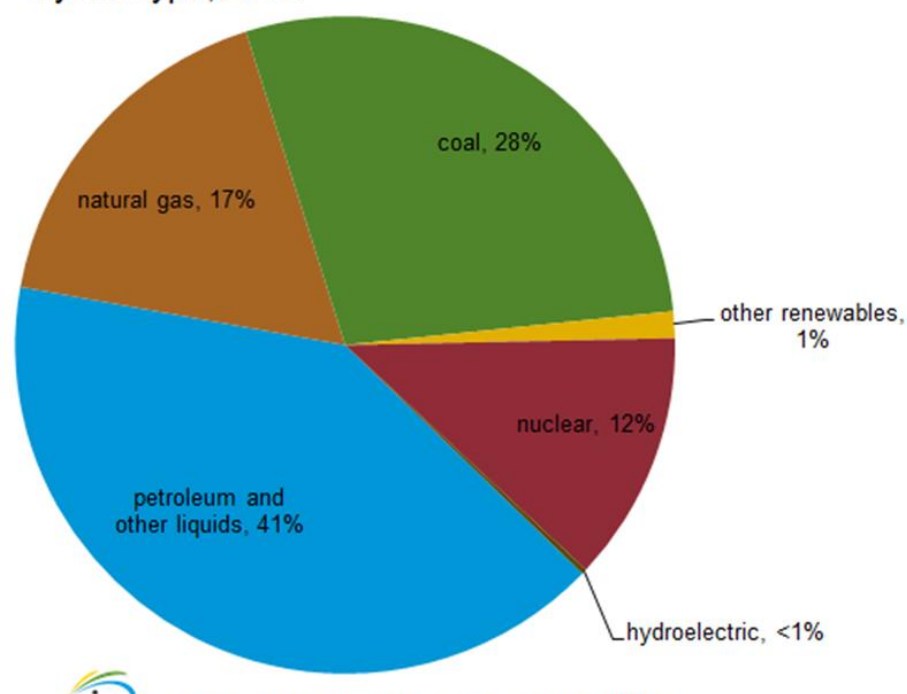

eia Source: U.S. Energy Information Administration

Figure 37. Energy in South Korea

South Korea differs from China in the reliance upon nuclear power, where the country is a world leader in plant constructions. Reducing its GHG emissions, South Korea will have to rely much more upon renewable energy sources, as well as reducing coal and oil for imported gas or LNGs.

Summing up: Defection in a game of state coordination is always a relevant strategy option. It may be triggered by various reasons, like changing beliefs or preference for economic growth over the environment. What the US and Australia decides will have global repercussions.

\section{Conclusion}

The election of Donald Trump as the new US president has opened up a central weakness in the COP21 Agreement, namely the risk of governments reneging, i.e. defecting upon coordination promises. If the US goes back to the burning of massive coal without sequestration, then this is almost like a death signal to the whole COP21 project. Other countries may follow like Australia, South Korea, Japan and India.

It is vital to underline that Asian countries are attempting two different things during the next decades:

- Their governments wish to comply with decarbonisation along the policy lines of the COP21 Agreement; thus fossil fuels must be reduced considerably, and coal perhaps entirely eliminated or sequestrated.

- The Asian economic miracles wish to strengthen their newly won affluence by further economic growth; some speak of 40-50 per cent more energy. But can decarbonisation and energy augmentation go along side by side

Trying to combine these goals puts an enormous pressure upon investment and innovation, as renewables and atomic power are considered the means to these goals. The tasks ahead of the fulfilment of decarbonisation objectives are so large that governments and regional coordination bodies need to focus almost all attention upon them.

The UNFCCC has most ardent tasks to manage in the near future. Besides ruling out defection, it must clarify what support countries can count upon from the famous Super Fund, a la Stern (2007). Otherwise the poor and medium affluent countries cannot plan the future ahead of the COP21 goal I and goal II.

\section{References}

\section{GDP sources:}

OECD National Accounts data files

World Bank national accounts data - data.worldbank.org 


\section{GHG and energy sources:}

BP Energy Outlook 2016.

British Petroleum Statistical Review of World Energy 2016Literature

Energy Information Administration. Washington, DC.

EU Emissions Database for Global Research EDGAR, http://edgar.jrc.ec.europa.eu/

EU Joint Research Centre Emission Database for Global Atmospheric Research http://edgar.jrc.ec.europa.eu/overview.php

International Energy Agency. Paris.

UN Framework Convention Climate Change -http://unfccc.int/ghg_data/ghg_data_unfccc/time_series_annex_i/items/3814.php

World Bank Data Indicators, data.worldbank.org

World Resources Institute CAIT Climate Data Explorer - cait.wri.org

\section{Literature}

Barro, Robert J. (1991). Economic Growth in a Cross Section of Countries. The Quarterly Journal of Economics, 106(2), 407-443.

Barro, Robert J., \& Xavier X. Sala-i-Martin. (1992). Convergence. Journal of Political Economy, 100(2), 223-251.

Barro, Robert J., \& Xavier X. Sala-i-Martin. (1995). Economic Growth. McGrow Hill

Hayek, F. (1991). Fatal Conceit. The errors of socialism. Chicago: University of Chicago Press.

Kaya, Y., \& Yokoburi, K. (1997). Environment, energy, and economy: Strategies for sustainability. Tokyo: United Nations University Press.

Malthus, T. (1798, 2008). An Essay on the Principle of Population. Oxford: Oxford U.P.

Ramesh, J. (2015). Green Signals: Ecology, Growth and Democracy in India (2015). Oxford : Oxford University Press.

Rostow, W. W. (1960). The Stages of Economic Growth: A Non-Communist Manifesto. Cambridge: Cambridge University Press.

Sachs, J. (2015, August 10th). Sustainable Development for Humanity's Future. Retrieved from http://jeffsachs.org/2015/08/sustainable-development-for-humanitys-future/

Sachs, J.D. (2015). The Age of Sustainable Development. New York: Columbia University Press.

Stern, N. (2007). The Economics of Climate Change. Oxford: OUP..

\section{Copyrights}

Copyright for this article is retained by the author(s), with first publication rights granted to the journal.

This is an open-access article distributed under the terms and conditions of the Creative Commons Attribution license (http://creativecommons.org/licenses/by/4.0/). 